УДК 378.147: 004.77

UDC 378.147: 004.77

DOI: $10.31475 /$ ped.dys.2018.25.08

ТЕТЯНА ГОРПІНІЧ,

кандидат педагогічних наук, доцент

(Украӥна, Тернопіль, ДВНЗ «Тернопільський державний медичний університет ілені І. Я. Горбачевського МОЗ Украӥни», майдан Волі, 1)

TETIANA HORPINICH,

candidate of pedagogical sciences, assistant professor

(Ukraine, Ternopil, I. Horbacheusky Ternopil State Medical University, maidan Voli, 1)

ORCID: 0000-0003-2160-4535

\title{
Періодизація розвитку медичної освіти в США
}

\section{Periodization of the Development of Medical Education in the USA}

У статті здійснено спробу періодизації становлення медичної освіти в США. Проведено терлінологічний аналіз основних понять зазначеної проблели - "період", "періодизація", "критерій періодизащії» тощо. Обгрунтовано основні критерї, взяті за основу періодизацї̈, а саме домінуюча науково-педагогічна парадигма, в межах якої розвивається вища медична освіта, та характер політичних, соціальних та еконолічних подій в країні. За основу періодизацї за першим критеріем було взято публікацію масштабного аналітичного дослідження медичної освіти в США та Канаді, яке отримало назву Звіту Флекснера і стало підгрунтям докорінних рефборм алериканської медичної освіти. На основі иього критерію виділено дореббормений та післярефборлений періоди. За другий критерій періодизацї взято характер політичних, соиіальних та еконолічних подій в крайні та виділено 5 періодів: доколоніальний, колоніальний, період становлення національної систели медичного забезпечення, період ребборлування та удосконалення національної систели медичної освіти, розвиток систели медичної освіти в умовах глобалізацї. В межах кожного періоду виявлено властиві йому рушійні сили та тенденції.

Ключові слова: періодизація, період, критерій періодизацї, медична освіта, США.

The article is devoted to the question of the periodization of the educational system in the USA, which is important for revealing its origins, internal regularities, scientific generalization in historical and pedagogical science. The aim of the given research is to identify the main periods and leading trends in the development of medical education in the United States.

The general characteristics of the concepts of "periodization", "periodization criterion", "period" are determined. Different approaches to the problem of periodization of educational systems are analyzed. On the basis of the analysis of different approaches to the definition of criteria and the implementation of the periodization of individually studied phenomena, the main criteria for substantiation of the historical and pedagogical periodization of higher medical education development in the USA are established: the dominant scientific-pedagogical paradigm, within which higher medical education develops, and the nature of political, social and economic events in the country. On the basis of these criteria, main periods are characterized, which in turn include specific internal stages or sub-periods.

The basis of the periodization according to the first criterion was a large-scale analytical study of medical education in the United States and Canada, which was called the Flexner Report and became the basis of radical reforms of American medical education. Thus, the pre-reform period was characterized by the "student" model of medical education, the large number of uncredited private medical schools, the lack of scientific research within the educational institutions, whereas the postreform period presented a new paradigm of professional training for doctors, which included the academic excellence of education itself, the expansion of the scope of fundamental and natural disciplines studied by medical students, introduction of large-scale scientific research within educational institutions. On the basis of the second criterion for periodization, five periods are distinguished: precolonial, colonial, period of building national health care system, period of reforming system of medical education, development of medical education under the conditions of globalization.

It is established that at each stage, the tasks were addressed to meet the educational needs of American society. Thus, within each period, the driving forces and specific trends are identified.

Key words: periodization, period, periodization criterion, medical education, the USA. 
Вступ / Introduction. Розвиток освіти як складної системи і його результати мають соціальне значення, спрямованість, певні просторові межі, зумовлені соціально-історичним розвитком конкретної держави, її культури. У зв'язку з цим вивчення освітньої системи США, визначення їі тенденцій і основних етапів нерозривно пов'язане з історією самої країни.

В сучасних умовах проблема періодизації освітньої системи в США набуває особливої гостроти. Це пов'язано, перш за все, з появою актуальних і маловивчених питань з історії освіти США проблеми періодизації історичної науки, чисельності, складу, грамотності статевовікових груп населення США на різних етапах їх розвитку, критичного аналізу освітніх реформ, їх впливу на соціально-економічну ситуацію в країні і навпаки, роль міграційних процесів тощо.

Питання періодизації освітньої системи в США мають важливе значення для виявлення їі витоків, внутрішніх закономірностей, що важливо для наукового узагальнення в історикопедагогічній науці. Періодизація визначае сутність генезису освітньої системи, характерної для конкретної країни, регіону або людства в цілому.

Мета та завдання / Aims and tasks. Мета статті - виявити основні періоди та провідні тенденції розвитку медичної освіти в США.

Завдання дослідження:

1. Теоретично обгрунтувати і здійснити періодизацію розвитку медичної освіти в США.

2. Виявити основні тенденції розвитку медичної освіти в США в межах кожного періоду.

Методи / Methods. Під час дослідження було використано елементи контент-аналізу, метод періодизації, порівняльно-історичний, хронологічний метод.

Результати / Results. Деякі аспекти вищої освіти США досліджено вітчизняними вченими: Н. Бідюк (освіта дорослих), Н. Горішна (підготовка соціальних працівників), І. Зварич (оцінювання знань студентів), О. Кокор (підготовка викладачів іноземних мов), О. Корнієнко (підготовка бакалаврів), О. Магдюк (підготовка шкільних консультантів), О. Мартинюк (підготовка магістрів технічного перекладу), Т. Олендр (моніторинг якості вищої освіти), Р. Шаран (професійна підготовка магістрів інформаційних технологій), Н. Щур (підготовка вчителя біології) та інші.

Окремі питання американської вищої освіти досліджено більш детально. Зокрема, дисертаційне дослідження О. Стойки присвячене особливостям трансформаційних процесів, які відбуваються у вищій школі США впродовж останніх десятиліть і стосуються нових видів фінансової допомоги студентам, підготовщі абітурієнтів до вступу у вищі навчальні заклади, вдосконаленню дистанційної освіти, питанням навчання етнічних меншин тощо. Авторкою здійснено типологію інституційних перетворень у вищій освіти США та існуючих моделей управління перетвореннями. М. Петречко здійснено аналіз педагогічної спадщини Х. Паркхерст у контексті педагогіки вищої школи США першої половини XX ст. Дисертаційне дослідження О. Калініної присвячене аналізу системи управління якістю освіти у США.

Комплексний аналіз проблем реформування загальної середньої освіти в США 1950-1990-х рр. здійснено М. Шутовою. Авторкою визначено, що філософсько-методологічною основою розвитку загальної середньої освіти в США е концепщія реформаторської педагогіки, яка полягае в практичній спрямованості навчання та виховання. З'ясовано, що еволюція становлення загальної середньої освіти в Америці відбувалася за двома хронологічними періодами передінформаційного та інформаційного суспільства. Попри це, спроби періодизації розвитку американської вищої освіти досі е нечисельними та неповними. Це підсилюе значущість пропонованої розвідки.

Зупинимося детальніше на визначенні основних понять зазначеної проблеми. Термінологічний аналіз довідкової літератури допоміг визначити загальні характеристики понять «періодизація», «критерій періодизації,, «період», які стали основою для ключових понять нашого дослідження.

Періодизація - це розподіл на періоди (Бусел В., 2004). Розкриттю якісних змін в ході подій і явищ, які вивчаються, їх форм і змісту на певних етапах історичного розвитку сприяе метод періодизації. Метод періодизації допомагає не тільки визначенню якісних і кількісних перетворень педагогічних явищ, а й з'ясуванню причини цих змін (Бусел В., 2004).

Академічний тлумачний словник української мови визначае період як історичний етап у суспільному або культурному розвитку країни, народу, що характеризуеться визначними подіями, явищами або процесами (Білодід I., 1975). За визначенням, поданим у сучасному тлумачному словнику української мови, період - це проміжок часу, обмежений певними датами, подіями тощо, час, коли відбувається яка-небудь подія, триває дія, розгортається чиясь діяльність, чи позначений існуванням, наявністю чого-небудь (Яковлева А., Яковлева Т., 2017). Тлумачний словник української мови визначае період як певну стадію, фазу чого-небудь, історичний етап у суспільному або культурному розвитку країни, народу, суспільного явища, що характеризуеться визначними подіями, явищами або процесами (Ващенко Л., 2012). 
Отже, період - це проміжок часу, обмежений датами, подіями; час, коли відбувається якась подія, певна стадія, фаза чогось; історичний етап в громадському чи культурному розвитку країни, народу, який характеризуеться важливими подіями, явищами або процесами; проміжок часу, протягом якого відбувається якийсь регулярно повторюваний процес або рух.

Важливим аспектом історико-педагогічної періодизації розвитку освіти е питання висвітлення критеріїв, які допоможуть визначити під час дослідження міру оцінки історико-педагогічних факторів, рушійних сил процесу розвитку вищої медичної освіти. Критерій періодизації - це той історичний фактор, який розкривае основний зміст певного відрізка часу конкретного історичного процесу, або підстава для оцінки, класифікації чогось.

Наукове визначення критерію дали представники фрілософської течії діалектичного матеріалізму, згідно з яким критеріем істини е суспільно-історична практика (Шинкарук В., 1986). Критерієм істини називають міру для визначення достовірності наших знань про предмети, явища об'єктивної дійсності, це людська практика, практична похідна діяльності людей (Кондаков Н. 1975). Виходячи 3 вище викладеного, дослідження передбачає вивчення явищ історичної об'єктивної дійсності як міру достовірності наших знань про досліджуваний предмет. Вивчення суспільно-історичної практики, в нашому випадку розвитку освіти в США, зокрема вищої медичної освіти, розкрие історико-педагогічні чинники, а критерії будуть мірою для визначення рушійної сили в розвитку вищої медичної освіти. Сама ж історична практика становлення і розвитку вищої медичної освіти як практична похідна людської діяльності вкаже шляхи їх вдосконалення.

Як бачимо, проблема періодизації історії освітньої системи е проблемою методологічного порядку. Періодизація історії освітньої системи США дуже тісно пов'язана з періодизацією всесвітньої історії та історії самої країни. Разом з тим, як відомо, будь-яка наука мае конкретні особливості своєї періодизації, які відображають специфіку розвитку ï процесу на різних історичних етапах. У цьому контексті історико-педагогічна наука не е винятком, оскільки вона вивчае витоки становлення і тенденції розвитку освітніх процесів, педагогічної думки в усіх їх протиріччях.

Загалом, у сучасній історико-педагогічній науці є різні підходи до проблеми періодизації освітніх систем. Як бачимо, складність ціеї проблеми полягає в тому, що дуже не просто встановити единий критерій, основу, які здатні задовольнити потребу обгрунтованого членування i всесвітнього історичного процесу, і регіональних його історій. Конкретні результати освітніх реформ взагалі не можна вивести з їхнього задуму і виконання, оскільки їх вплив на освіту опосередковуеться різними соціокультурними чинниками.

Незважаючи на наявність вагомих досліджень, в американській та вітчизняній історикопедагогічній науці недостатньо обгрунтованою є характеристика основних періодів розвитку американської вищої медичної освіти. Характеризуючи етапи розвитку цієї системи освіти, слід відштовхуватися від тих факторів, які здійснили вплив на становлення і розвиток системи медичної освіти.

Обговорення / Discussion. У вітчизняній науковій літературі існують різні погляди на проблему критеріїв періодизації. Так, В. Курило вважае, що при розробці періодизації треба враховувати істотні характеристики системи освіти (Васильева С., б.д.). При типологізації освітніх реформ Л. Березівська визначае такі критерії, які можна взяти за основу при періодизації розвитку освіти: суспільна значущість реформ, їх персоніфікаційна характеристика, масштабність і перспективність, змістовна характеристика, процесуальні зміни, усталені назви за керівниками реформ (Березівська Л., 2009). Феномен особистості враховуе О. Сухомлинська, коли розглядає проблему періодизації розвитку педагогічної думки як одну з найбільш складних, комплексних і багаторівневих проблем наукового знання (Сухомлинська О., 2003).

Таким чином, періодизація - це науково обгрунтований розподіл хронологічних меж розвитку освітньої системи на періоди, де період - це проміжок часу, протягом якого відбувається розвиток навчальних закладів, пов'язаний з соціальним розвитком нашого суспільства та держави; критерій періодизації - міра ощінки історико-педагогічного фрактора, який $є$ рушійною силою процесу розвитку навчальних закладів в певний період дослідження.

Досі спроби періодизації американської медичної освіти були здійснені окремими американськими вченими (Ж. Міллер, Р. Гайгер, Ф. Рудольф, Е. Сальсберг, Дж. Форте). У вітчизняних наукових розвідках зустрічаються лише поодинокі спроби загальноісторичної періодизації американської вищої освіти (М. Шутова, О. Стойка, О. Тарасова), які, в основному, наслідують традицію американських істориків освіти (Д. Теннер, Г. Колінз, В. Джейнс, Т. Дай, Дж. Бест, Л. Кремін). Аналіз різних підходів до визначення критеріїв і здійснення періодизації окремо досліджуваних феноменів дозволяе нам сформулювати і встановити основні критерії для обгрунтування історико-педагогічної періодизації розвитку вищої медичної освіти США:

1) домінуюча науково-педагогічна парадигма, в межах якої розвивається вища медична освіта; 
2) характер політичних, соціальних та економічних подій в країні.

На основі зазначених критеріїв можна виділити i предметно схарактеризувати основні періоди, які, в свою чергу, включають специфічні внутрішні етапи чи субперіоди.

За основу періодизації за першим критеріем було взято масштабне аналітичне дослідження медичної освіти в США та Канаді, яке отримало назву Звіту Флекснера (The Flexner Report) і стало підгрунтям докорінних реформ американської медичної освіти. Його результати було опубліковано 1910 р. (Flexner A., 2018). Саме в ньому вперше описано близьку до сучасної модель медичної освіти. Центральним елементом цієї навчальної моделі розуміння наукових принципів, що лежать в основі фрізіології людини і розвитку патологічних процесів, є прийняття клінічних рішень. У своїй праці А. Флекснер вказав на небезпечну тенденщію відмови від справжнього пізнавального інтересу на користь прагматизму - в науці, в освіті і в людському мисленні загалом (Чайковський Ю., Хламанова Л., 2015). Концепція А. Флекснера щодо реформи медичної освіти складалася 3 трьох компонентів: 1) внесення до навчальних планів окрім вивчення фізіології та морфології, які він вважав необхідною передумовою медищини, ще і природничих дисциплін та статистики, що мало сприяти розвитку логічного мислення; 2) добре структурованого клінічного навчання, заснованого на досвіді клінічної школи Джона Гопкінса; 3) наукової діяльності, на яку, крім суто наукових завдань, покладалася важлива навчальна місія. Окрім цього, А. Флекснер вважав, що наукова діяльність в клініці буде сприяти поліпшенню лікування хворих (Чайковський Ю., Хламанова Л., 2015). Загалом, модель навчання медицини А. Флекснера вважається «академічною», зоріентованою на університетське навчання, на відміну від існуючої раніше у США «учнівської» (apprenticeship) моделі. Власне, академічність навчання, наявність підготовки 3 фундаментальних дисциплін надає можливість лікарю діяти не лише за інструкціями, а й робити діагностичний та лікувальний вибір у ситуаціях невизначеності, які часто виникають в умовах клініки. Саме така можливість відрізняе лікаря від інших медичних працівників, дії яких жорстко регламентовані службовими інструкціями (Чайковський Ю., Хламанова Л., 2015).

Таким чином, дорефборлений період характеризується «учнівською» моделлю здобуття медичної освіти, великою кількістю неакредитованих приватних медичних шкіл, відсутністю наукових досліджень в межах навчальних закладів. Післярефборлений період представив нову парадигму професійної підготовки лікарів, яка передбачала академічність самої освіти, розширення кола фундаментальних та природничих дисциплін, які вивчали студенти-медики, впровадження масштабних наукових досліджень в межах навчальних закладів, скорочення числа медичних шкіл за рахунок жорсткого інспектування та акредитації.

За другий критерій періодизації було взято характер політичних, соціальних та економічних подій в країні та виділено 5 періодів.

Доколоніальний період (заселення території країни першими племенами - 1620 р.) характеризувався відсутністю единої централізованої стандартизованої педагогічної системи. Передача знань, в тому числі медичних відбувалася в усній формі і базувалася на багатовіковому емпіричному досвіді корінних жителів Америки.

Знання про лікування захворювань існували у формі народної медицини. Лікуванням захворювань займалися знахарі, які вважалися носіями знань про людину, набутих попередніми поколіннями. Загалом в доколоніальний період було накопичено значний обсяг досвіду та інформації про фітотерапію, лікування ран, легких недугів, контрацепцію, основи гігієни.

Колоніальний період (1620-1783 рр.) розпочався із поселенням пуритан-емігрантів на території США. Основними здобутками цього періоду е запровадженням інституту обов'язкової освіти, відкриття перших колоніальних коледжів, становлення медичної освіти у формі «учнівської» моделі навчання.

Загалом, медична освіта в цей період розвивалася відносно повільно. Впродовж тривалого часу підготовка медичних працівників здійснювалася за межами країни - в університетах Свропи (Единбург, Лондон, Лейден). Так, у XVIII ст. 117 американських лікарів здобули медичну освіту в університеті Единбурга в Шотландії (Miller G., 1976). Більшість медичних працівників здобували знання як учні практикуючих лікарів (модель учнівства - apprenticeship). Таке навчання тривало, як правило, три роки і полягало у постійних спостереженнях та безпосередній допомозі у роботі лікаря. Через брак кваліфікованих працівників населенню, як і раніше, часто доводилося вдаватися до практик народної медицини. Інколи такі послуги надавали церковнослужителі (Medical education, n.d.).

Ситуація змінилася напередодні Війни за незалежність. На хвилі зростання національної свідомості та необхідності підготовки власних медичних працівників для задоволення громадянських та військових потреб 1765 р. з'являеться перша медична школа при коледжі Філадельфії. 1767 р. засновано медичний факультет при Королівському коледжі в Нью-Йорку, в 
якому 1770 р. вперше в історії медичної освіти США було присвоено ступені доктора медицини (Cooke J., 1993). 1782 р. засновано Медичну школу Гарвардського університету.

По суті, здобуття незалежності США стало точкою відліку формування американської нації, ії ідентичності, менталітету, що дало підставу виокремити наступний період розвитку американської медичної освіти. Окрім того, що період становлення національної системи медичного забезпечення (1783-1910рр.) був часом фундаментальних соціально-політичних перетворень, він відіграв важливу роль у становленні медичної освіти США. Внаслідок активних політичних дискусій, становлення законодавчої бази всієї країни загалом, територіальної експансії, розвитку економіки, виникає потреба у працівниках економічної, політичної, медичної, освітньої сфери.

Хоча в середині XIX ст. американська медична освіта була недостатньо якісною, реформа системи вже почалася. В основі трансформації лежало кілька фракторів: революція в експериментальній медицині, що відбувалася в Європі; значна кількість американських лікарів, які подорожували до Європи (зокрема, Німеччини) для вивчення лабораторних методів дослідження; поява сучасного університету в Америці; розробка системи масової освіти для забезпечення кваліфікованих абітурієнтів університету; плекання ідеї фрілантропії серед багатьох заможних підприемців. Разом ці чинники забезпечили інфраструктуру нової системи медичної освіти.

Саме цей період став початком створення сучасної системи медичної освіти в США, яке відбулося в два етапи. Перший етап, який розпочався в середині XIX ст., відзначився революцією в ідеях щодо мети та методів медичної освіти. Після закінчення Громадянської війни педагогимедики почали відмовлятися від традищійного уявлення про те, що здобуття медичної освіти полягає виключно у вивченні фактів через усне запам'ятовування. Навпаки, нова мета медичної освіти полягала у виробленні проблемного та критичного мислення, вмінні знаходити та оцінювати інформацію. Для џього було зменшено роль традиційних дидактичних методів читання лекщій та опрацювання підручників та закцентовано на важливості самоосвіти та навчання шляхом виконання практичних завдань. Завдяки лабораторній роботі та клінічним заняттям студенти повинні були стати активними учасниками навчання, а не пасивними спостерігачами, як раніше.

Таким чином, в цей період відбувається реформування існуючої «учнівської» моделі підготовки лікарів, утверджуеться уявлення про роль медичної освіти як вироблення проблемного та критичного мислення, вміння знаходити та оцінювати інформацію. З'явилася ідея відкриття нових знань через клінічні дослідження. Це сприяло перетворенню медичних шкіл із автономних установ у частини університетів як потужних навчально-дослідницьких закладів.

Цей період характеризуеться успішним подоланням кількох соціальних викликів, які постали перед країною. Одним із них стала боротьби із сегрегаціею у галузі освіти загалом та медичної освіти зокрема. Проте найбільші здобутки цього періоду стосувалися власне структури навчання в медичній школі. Так, було додано нові дисципліни та лабораторні й наукові роботи до навчального плану, впроваджено чотирирічний навчальний план 3 дев'ятимісячними семестрами, окремі приватні медичні школи поступово почали заміщуватися медичними школами при університетах. Впродовж цього часу у медичних школах було накопичено великі фінансові ресурси, збудовано нові лабораторії, впроваджено етапи інтернатури та резидентури як необхідні віхи професійної підготовки лікаря.

Перші тривалі реформи в медичній освіті відбулися, коли Гарвардський та університети Пенсильванії й Мічигану продовжили курс навчання до трьох років, додали нові дисципліни та лабораторні та дослідницькі роботи до навчального плану та почали влаштовувати до штату вчених в галузі медицини. 1893 р. було відкрито Медичну школу Джона Гопкінса. Вона відразу стала моделлю, на яку оріентувалися всі інші медичні школи, як і Університет Джона Гопкінса в 1876 р. став моделлю для сучасного американського дослідницького університету. Обов'язковою вимогою для вступу стало попередне отримання диплому коледжу, особливість, яка і досі відрізняе американську медичну освіту від європейської. Було впроваджено чотирирічний навчальний план 3 дев'ятимісячними семестрами, академічні групи були невеликими. Контроль за навчальними досягненнями здійснювався часто, лабораторні та клінічні заняття керувалися вченими, а дослідницька робота в галузі медицини стала одним із головних завдань медичної освіти. У 1880 1890-х pр. навчальні заклади по всій країні почали наслідувати ці провідні медичні школи, розпочавши кампанію з реформування американської медичної освіти.

Необхідною стала як інституційна, так і інтелектуальна революція, яка відбулася між 1885 i 1920 рр. Впродовж цього часу у медичних школах було накопичено значні фінансові ресурси, зібрано висококваліфікованих штатних викладачів, придбано сучасні клінічні засоби. Медичні школи, які раніше існували автономно, стали тісно пов'язаними з університетами та навчальними 
лікарнями. Це стало передумовою і поштовхом до подальших змін в межах системи медичної освіти США.

Період реббормування та удосконалення національної систели медичної освіти (19101975 рр.) став відповіддю освітньої системи країни на ті проблеми, які постали перед США в середині XX ст. Як згадувалося, 1910 р. А. Флекснер опублікував доповідь про стан медичної освіти в США та Канаді. У цій книзі він описав ідеальні умови для медичної освіти за прикладом Медичної школи Джона Гопкінса, і несприятливі умови, які все ще існували в більшості медичних шкіл. Хоча Звіт Флекснера не зробив достатнього інтелектуального внеску в обговорення того, як слід навчати лікарів, він наблизив реформу медичної освіти до реального життя громадян, перетворивши те, що раніше було приватним питанням у межах самої професії, у нагальне суспільне питання.

Цей період також важливий становленням інституту інтернатури та резидентури. Під час Першої світової війни медична освіта зосереджувалася майже виключно на додипломній медичній підготовці, на завершення якої студент отримував ступінь доктора медицини. Оскільки більшість випускників медичних шкіл працювали в сфері загальної практики, чотири роки навчання вважалися належним часом для підготовки. Проте, до Першої світової війни, об'ем медичних знань, методик і практик суттєво зріс. Впродовж чотирирічного курсу викласти весь спектр накопичених знань було неможливим. Відповідно, період інтернатури після закінчення основного навчання став обов'язковим стандартом для кожного лікаря. До середини 1920-х років проходження інтернатури вимагали вже від усіх випускників медичних навчальних закладів США.

Згодом медична освіта США зіткнулася ще 3 однією проблемою: задоволення потреб випускників, які пройшовши курс інтернатури, бажали продовжити навчання у більш вузькій клінічній спеціальності (наприклад, офтальмологія, педіатрія чи хірургія) або в галузі клінічних досліджень. Цю проблему було вирішено шляхом впровадження інституту резидентури кількарічного стажування у клініках. Таким чином, на завершення цього періоду американська медична освіта була готова до викликів, які постали перед нею в середині XX ст.

Період реформування та удосконалення національної системи медичної освіти став показником готовності США до викликів часу. Внаслідок двох масштабних військових конфліктів та економічного потрясіння під час Великої депресії, які сталися протягом доволі короткого періоду американська освітня система почала змінюватися та розвиватися.

Вихід із масштабної економічної кризи було забезпечено економічною політикою, яку проводила адміністрація президента Ф. Рузвельта, передвиборна платформа якого обіцяла так званий «новий курс». 1932 р. Комісією з вартості медичного обслуговування опубліковано Звіт про стан охорони здоров'я в країні, який засвідчив, що для багатьох груп населення кваліфікована медична допомога була недоступною. В результаті цього 1934 р. за ініціативою Американської медичної асоціації Палатою представників було прийнято рішення про впровадження обов'язкового медичного страхування. Згодом, 1935 р. було прийнято Закон про соціальне забезпечення (Social Security Act), який передбачав систему виплат пенсій за рахунок підприемців та страхового внесок на охорону здоров'я. Так реформування соціальної сфрери, з-поміж інших переваг, сприяло підвищенню престижу професії лікаря.

Під час Другої світової війни стандарти медичної освіти зростали, попри те, що розвиток вищої освіти в США було уповільнено у зв'язку з відпливом молодих людей до армії. 1940 р. було опубліковано Доповідь Комісії з вищої медичної освіти, в якій вперше описано процес підготовки інтернів та резидентів та запропоновано рекомендації з їі покращення. Комісію з зв'язків 3 медичною освітою було створено в 1942 p. (Poncelet A., Hirsh D., 2016). Участь США у Другій світовій війні відіграла важливу роль у розвитку медицини і медичної освіти. Впродовж цього періоду відбулося масштабне накопичення знань в галузі військової медищини та дотичних до неї спеціальностях, тому цей період характеризуеться закріпленням інституту резидентури.

Повоенний період надав поштовх розвитку вищої освіти не лише у зв'язку з виникненням нових суспільних потреб, а й через притік молодих людей, які мали потребу у здобутті освіти. Так, у 1944 р. урядом США було встановлено освітні привілеї для ветеранів і учасників Другої світової війни прийняттям так званого Солдатського білля про права (Servicemen's Readjustment Act / GI Bill) (Fraser J., 2009). Біллі про прана ветеранів, прийняті після Другої світової й корейської воєн (впроваджені відповідно в 1944 і 1952 рр.) справили значний вплив на розвиток вищої освіти завдяки наданню мільйонам ветеранів можливості вступити до коледжів.

У відповідь на запуск СРСР штучного супутника було прийнято Закон про освіту в галузі національної оборони (National Defense Education Act) 1958 р. Цей закон прямо визначив основну мету державної політики в галузі освіти - зміцнення військово-технічного потенціалу США. Загалом період 1945-1960рр. - це етап максимально інтенсивного розвитку системи освіти в США, 
зумовлений прагненням забезпечити військову перевагу. Модернізація здійснювалася шляхом якісного оновлення технічного устаткування навчального процесу, форм і методів навчання (Шутова М., 2004).

В галузі фрінансування вищої медичної освіти також відбулися суттеві зміни. У 1950-х рр. почали видаватися федеральні гранти на підтримку медичних шкіл та університетських лікарень. $\mathrm{Y}$ практику входить отримання грантів на наукові дослідження (History of the U.S. ..., n.d.). Відображаючи зміни у суспільстві, медичні школи також стали більш репрезентативними для різноманітних груп населення, яке вони обслуговували.

Рішучі зміни наступили у 1960-і рр., які відзначилися значними успіхами в різних сферах життя, в тому числі в медицині, і сплеском громадської активності. В академічних колах дедалі наполегливіше звучали думки про необхідність перебудови медичних та освітніх структур. У зазначений період відбулося перетворення вищої школи США в багатоступеневий механізм. Одночасно активізувалися процеси інтеграції та кооперації ВНЗ, що дозволило здійснювати міждисциплінарний підхід до навчання. Перехід американської вищої школи на міждисциплінарну основу підготовки фахівців привів до структурних змін і всередині самих університетів, а саме до створення міждисциплінарних департаментів. Поряд зі структурними змінами у вищій школі США відбулися і значні кількісні зрушення, пов'язані зі зміною чисельності різних типів вищих навчальних закладів, студентів, прийнятих на навчання, професорсько-викладацького штату.

У цей період у вищій школі США було впроваджено цілу низку нових напрямів в організації навчального процесу: міждисциплінарний принцип навчання, гуманітаризація освіти, інтенсифікація навчального процесу; система керованої (контрольованої) фокультативності, система індивідуалізованого навчання (система тьюторства), застосування активних методів у процесі навчання.

Таким чином, в цей період актуальним стало питання забезпечення рівних громадянських прав та доступності освіти, яке стало успішно вирішеним за рахунок грантів на наукові дослідження. В галузі фрінансування вищої медичної освіти також відбулися суттеві зміни, оскільки у відповідь на фінансові виклики почали видаватися федеральні гранти на підтримку медичних шкіл та університетських лікарень. Одночасно активізувалися процеси інтеграції та кооперащії ВНЗ, що дозволило здійснювати міждисциплінарний підхід до навчання. Перехід американської вищої школи на міждисциплінарну основу підготовки фрахівців привів до структурних змін і всередині самих університетів, а саме до створення міждисциплінарних департаментів. Всі ці зміни стали й основою, і результатом нової історичної реальності глобалізованого суспільства.

Зупинимося детальніше на визначенні поняття «глобалізація». Наприкінці 1970-х рр. цей термін увійшов в науковий обіг соціології, згодом увійшовши в ширший вжиток. Під глобалізацією розуміють процес створення единого культурного, економічного правового, освітнього та інформаційного простору. Основними ознаками глобалізованого суспільства є стандартизація та уніфікація різних сфрер людської діяльності, створення транснаціональних компаній, зростання ролі мережі Інтернет та англійської мови.

Розвиток системи медичної освіти в уловах глобалізації (1975 - наш час.) характеризуеться

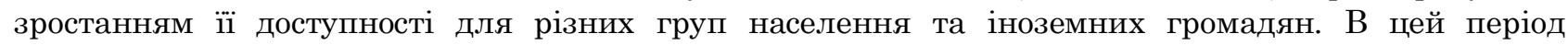
особливого значення набувають Академічні центри здоров'я - сплави медичної школи i університетської лікарні, які стали залучати найбільш кваліфрікованих фахівців з усього світу, ставши надзвичайно впливовими і складними закладами освіти та наукових досліджень.

Окрім цього, цей період характеризуеться особливо активною участю президентів США у формуванні освітнього курсу країни. Загалом цей період відзначається тенденцією істотного посилення державного регулювання вищої освіти як на законодавчому, так і на адміністративному рівні. Це проявилося в реформуванні системи федерального і штатного управління вищою школою, в зростанні значення системи законодавчого регулювання вищої освіти США. Стала відчутною стійка тенденція до зміни методів, технологій, форм здобуття вищої освіти з метою забезпечення індивідуалізації, гуманізації та інтенсифікації навчального процесу, в тому числі за допомогою розширення використання нових технологій в освітньому процесі.

Узагальнена пропонована періодизація розвитку системи медичної освіти США представлена у формі таблиці 1.

Висновки / Conclusions. Таким чином, дослідження історії становлення та розвитку системи медичної освіти в США дозволило виявити своєрідність розвитку ії окремих періодів, специфіку, пов'язану з соціально-економічним рівнем розвитку американського суспільства, тенденцію його культурного становлення в певний відрізок часу. На кожному етапі ставилися і вирішувалися завдання щодо задоволення освітніх потреб американського суспільства. Звичайно, пропонована 
схема періодизації розвитку освітньої системи не претендуе на остаточний і незаперечний варіант. Будь-яка періодизація $е$ приблизною і умовною. Встановити точну дату значних історикопедагогічних процесів, що залежать від тенденцій суспільного розвитку на тому чи іншому етапі історії, дуже складно, оскільки питання періодизації історії освітньої системи тієї чи іншої держави тісно пов’язані із загальними проблемами світорозуміння, рухом суспільства від одніеї соціальноекономічної формації до іншої, більш прогресивної.

таблиия 1

Узагальнена пропонована періодизація розвитку системи медичної освіти США

\begin{tabular}{|c|c|c|}
\hline & Період & Часові межі \\
\hline \multicolumn{3}{|c|}{$\begin{array}{c}\text { Критерій періодизації: домінуюча науково-педагогічна парадигма, в межах якої розвивається } \\
\text { вища медична освіта. }\end{array}$} \\
\hline 1 & Дореформений & $\begin{array}{l}\text { Заселення Північної Америки } \\
\text { племенами із Азії - } 1910 \text { р. }\end{array}$ \\
\hline 2 & Післяреформений & 1910 - наш час \\
\hline \multicolumn{3}{|c|}{ Критерій періодизації: характер політичних, соціальних та економічних подій в країні. } \\
\hline 1 & Доколоніальний період & $\begin{array}{l}\text { Заселення Північної Америки першими } \\
\text { племенами із Азії - } 1620 \text { р. }\end{array}$ \\
\hline 2 & Колоніальний період & $1620-1783$ pp. \\
\hline 3 & $\begin{array}{l}\text { Період становлення національної системи } \\
\text { медичного забезпечення }\end{array}$ & $1783-1910$ pp. \\
\hline 4 & $\begin{array}{l}\text { Період реформування та удосконалення } \\
\text { національної системи медичної освіти }\end{array}$ & $1910-1975$ pp. \\
\hline 5 & $\begin{array}{l}\text { Розвиток системи медичної освіти в } \\
\text { умовах глобалізації }\end{array}$ & 1975 - наш час \\
\hline
\end{tabular}

\section{Список використаних джерел / References:}

1. Березівська, Л. Д. (2009). Організаційно-педагогічні засади рефбормування шкільної освіти в Україні у XX cmoлimmi. (Дис. д-ра. пед. наук). Київ. / Berezivska, L. D. (2009). Orhanizatsiino-pedahohichni zasady reformuvannia shkilnoyi osvity $v$ Ukraiini u XX stolitti [Organizational and pedagogical principles of reforming the school education in Ukraine in the XX century]. Doctor's thesis. Kyiv. [in Ukrainian].

2. Білодід, І. К. та ін. (Ред.) (1975). Словник української мови. (Т. 6: П-Поїти). Київ: Наукова думка. / Bilodid, I. K. et al. (Ed.). Slovnyk ukraiinskoii movy. (T. 6: P-Poyity) [Dictionary of the Ukrainian language]. Kyiv: Naukova dumka. [in Ukrainian].

3. Бусел, В. Т. (Ред.). (2004). Великий тлумачний словник сучасної украӥнськоӥ мови. Київ, Ірпінь: ВТФ «Перун». / Busel, V. T. (2004). (Ed.). Velykyi tlumachnyi slovnyk suchasnoii ukraiinskoii movy [Great explanatory dictionary of modern Ukrainian language]. Kyiv, Irpin: VTF «Perun». [in Ukrainian].

4. Васильева, С. А. (б.д.). Критерии определения периодизации развития дошкольных учебньх учреждений разных типов в систеле образования Украины (вторая половина ХХ ст. - начало ХХІ ст.). Взято

http://lib.iitta.gov.ua/710487/1/\%D0\%A1\%D1\%82\%D0\%B0\%D1\%82\%D1\%82\%D1\%8F\%20\%E2\%84\%96\%2018.pdf (дата звернення 21.09.2018) / Vasil'eva, S. A. (n.d.). Kriterii opredeleniya periodizacii razvitiya doshkol'nyx uchebnyx uchrezhdenij raznyx tipov $v$ sisteme obrazovaniya Ukrainy (vtoraya polovina XX st. - nachalo XXI st.) [Criteria for determining the periodization of the development of preschool educational institutions of different types in the education system of Ukraine (second half of the XX century - the beginning of the XXI century)]. Retrieved from

http://lib.iitta.gov.ua/710487/1/\%D0\%A1\%D1\%82\%D0\%B0\%D1\%82\%D1\%82\%D1\%8F\%20\%E2\%84\%96\%2018.pdf (last accessed 21.09.2018) [in Russian].

5. Ващенко, Л. О. та ін. (Ред.). (2012). Тлумачний словник української мови: Близько 10 тисяч слів. Київ: Довіра. / Vashchenko, L. O. et al. (Ed). (2012). Tlumachnyi slovnyk ukraiinskoii movy: Blyzko 10 tysiach sliv [Interpreational Dictionary of the Ukrainian language]. Kyiv: Dovira. [in Ukrainian].

6. Кондаков, Н.И.(1975). Логический словарь-справочник. Москва: изд-во «Наука». / Kondakov, N. I. (1975). Logicheskij slovar'-spravochnik [Logical reference dictionary]. Moscow: izd-vo «Nauka». [in Russian].

7. Сухомлинська, О. В. (2003). Історико-педагогічний процес: нові підходи до загальних проблел. Київ: AПН. / Sukhomlynska, O. V. (2003). Istoryko-pedahohichnyi protses: novi pidkhody do zahalnykh problem [Historical and Pedagogical Process: New Approaches to Common Problems]. Kyiv: APN. [in Ukrainian].

8. Чайковський, Ю. Б. і Хламанова, Л. І. (2015). Додипломна вища медична освіта в Україні: що можна змінити вже сьогодні? Медична освіma, 1, 125-128. / Chaikovskyi, Yu. B. \& Khlamanova, L. I. (2015). Dodyplomna vyshcha medychna osvita v Ukraiini: shcho mozhna zminyty vzhe sohodni? [Postdoctoral Higher Medical Education in Ukraine: What can be changed today?]. Medychna osvita, 1, 125-128. [in Ukrainian]. 
9. Шинкарук, В. І. (Ред). (1986). Філософський словник (2-ге вид., переробл. і доповн.). Київ. / Shynkaruka, V. I. (Ed). (1986). Filosofskyi slounyk (2-nd ed., revised ed.) [Philosophical Dictionary]. Kyiv. [in Ukrainian].

10. Шутова, М. О. (2004). Проблеми рефборлування загальної середньої освіти в США (1950-ті-1990-ті pp.). (Дис. канд. пед. наук). Київ. / Shutova, М. О. (2004). Problemy reformuvannia zahalnoii serednoii osvity $v$ SSHA (1950-ti - 1990-ti rr.) [Problems of Reforming General Secondary Education in the USA (1950-1990 s)]. Candidate's thesis. Kyiv. [in Ukrainian].

11. Яковлева, А. М. і Яковлева, Т. М. (2017). Сучасний тлулачний словник украӥнської мови. Харків: Навчальна література. / Yakovleva, A. M. \& Yakovleva, T. M. (2017). Suchasnyi tlumachnyi slovnyk ukraiinskoii movy [Modern interpretation dictionary of the Ukrainian language]. Kharkiv: Navchalna literatura. [in Ukrainian]. English].

12. Cooke, J. E. (1993). Encyclopedia of the North American colonies (1 ${ }^{\text {st }}$ ed.). Charles Scribners Sons. [in

13. Flexner, A. (2018). Medical Education in the United States and Canada: A Report to the Carnegie Foundation for the Advancement of Teaching (Classic reprint). London: Forgotten Books. [in English].

14. Fraser, J. W. (2009). The School in the United States: A Documentary History. Routledge. [in English].

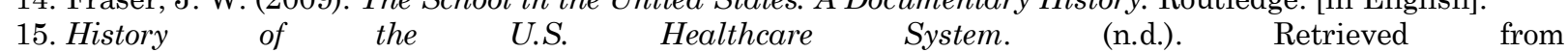
http://samples.jbpub.com/9781284043761/Chapter1.pdf (last accessed 11.10.2018). [in English].

16. Medical education. (n.d.). Retrieved from https://www.encyclopedia.com/history/ united-states-andcanada/us-history/medical-education (last accessed 14.09.2018). [in English].

17. Miller, G. A. (1976). Physician in 1776. Clio Medica, 11 (3), 135-146. [in English].

18. Poncelet, A. \& Hirsh, D. (2016). Longitudinal Integrated Clerkships: Principles, Outcomes, Practical Tools, and Future Directions. Gegensatz Press. [in English].

Дата надходження статті: «08» жовтня 2018 р.

Стаття прийнята до друку: «20» листопада 2018 р.

Горпініч Тетяна - доцент кафедри іноземних мов ДВНЗ «Тернопільський державний медичний університет імені I.Я.Горбачевського МОЗ України», кандидат педагогічних наук

Horpinich Tetiana - assistant professor of the English language department of the I. Horbachevsky Ternopil State Medical University, candidate of pedagogical sciences

\section{Цитуйте ию статтю як:}

Горпініч, Т. (2018). Періодизація розвитку медичної освіти в США. Педагогічний дискурс, 25, 63-71.

\section{Cite this article as:}

Horpinich, T. (2018). Periodization of the Development of Medical Education in the USA. Pedagogical Discourse, 25, 63-71. 